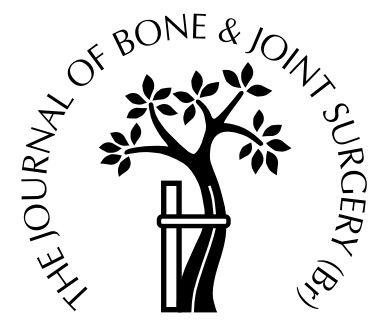

\title{
High-pressure irrigation increases adipocyte-like cells at the expense of osteoblasts in vitro
}

\author{
Mohit Bhandari, Emil H. Schemitsch \\ From McMaster University, Hamilton and St Michael's Hospital, Toronto, Canada
}

$\mathbf{H}$ igh-pressure lavage produces greater visible damage to bone at a macroscopic and microscopic level when compared with low-pressure lavage and can result in delay in the healing of fractures. Osteoblasts and adipocytes are derived from mesenchymal stem cells. Conditions which lead to bone loss often involve a switch from the osteoblast to adipocyte lineage. We have therefore examined the effect of high- and low-pressure irrigation on the differentiation of adipocytes.

Calvaria-derived bone cells were exposed to either low-pressure or high-pressure irrigation with normal saline. After 14 days the cells were fixed and the osteoblasts and adipocytes quantified using Oil Red $O$ to stain cytoplasmic lipid droplets (triglycerides) in the cells. Osteoblasts were quantified using a commercially available alkaline-phosphatase staining assay.

A standard quantitative reverse transcriptionpolymerase chain reaction (RT-PCR) was performed. Messenger RNA levels for osteocalcin, a marker of osteoblasts, and PPAR $\gamma 2$, a marker of adipocytes, were measured. High-pressure lavage resulted in an increase in adipogenesis of $50 \%$ when compared with low-pressure lavage.

Our findings suggest that high-pressure lavage may promote differentiation of mesenchymal stem cells towards the adipoctye lineage. This may have clinical significance in the development of delayed and nonunion after treatment of fractures of long bones.

J Bone Joint Surg [Br] 2002;84-B:1054-61.

Received 18 June 2001; Accepted after revision 11 March 2002

M. Bhandari, MD, MSc, Fellow

Department of Clinical Epidemiology and Biostatistics, McMaster University Health Sciences Centre, Room 2C12, 1200 Main Street West, Hamilton, Ontario, Canada L8N 3ZF.

E. H. Schemitsch, MD, FRCS C, Professor

Division of Orthopaedic Surgery, St Michael's Hospital, 55 Queen Street East, Suite 800, Toronto, Ontario, Canada M5G 1R6.

Correspondence should be sent to Dr M. Bhandari.

(C)2002 British Editorial Society of Bone and Joint Surgery 0301-620X/02/712532\$2.00
In vitro models of fractures of the tibial shaft have demonstrated at both macroscopic and microscopic level that high-pressure pulsatile lavage produces greater visible damage to bone than low-pressure lavage. ${ }^{1,2}$ Moreover, it has been reported that bone debridement under high pressures results in a decline in the early formation of new bone during healing of fractures. ${ }^{3}$

Recent studies have indicated that osteoblasts arising from mesenchymal stem cells can differentiate along several lineages. ${ }^{4-13}$ In the bone marrow, mesenchymal stem cells differentiate not only into osteoblasts, but also into adipocytes, and there is an inverse relationship between the formation of adipocytes and osteoblasts. Thus, some conditions which lead to bone loss often involve a switch from the osteoblast to adipocyte lineage. $9,11,14,15$ For example, with glucocorticoid-induced or age-related osteoporosis the decrease in the number of osteoblastic cells is accompanied by a parallel increase in the number of adipocytes. ${ }^{14,15}$ Furthermore, dexamethasone and certain fatty acids induce differentiation of adipocytes at the expense of the formation of osteoblasts in calvaria-derived cell-culture systems. 9,11 These studies suggest that adipocytes and osteoblasts are derived from an unknown common progenitor cell.

Given the decline in early bone formation after highpressure lavage, we hypothesised that the mechanism for this effect may be related to the differentiation of adipocytes. Our purpose therefore was twofold: 1) to examine the effect of high-pressure lavage on the number of adipocytes and osteoblasts in vitro; and 2) to evaluate whether low-pressure lavage limits the extent of the differentiation of adipocytes in vitro.

\section{Materials and Methods}

Calvarial cells were isolated from three-day-old C57B1/6 mice (Charles River Laboratories, St Constant, Canada) as described previously. ${ }^{16}$ Briefly, under low-power magnification, the parietal bones were exposed by sharp dissection of the overlying skin and subcutaneous tissue. Each calvaria was then carefully removed, minced and suspended in phosphate-buffered saline (PBS) before digestion with collagenase $(2.5 \mathrm{mg} / \mathrm{ml})$ for four hours at $37^{\circ} \mathrm{C}$. The resulting cells were washed, pelleted, and seeded into T-50 vented flasks at a concentration of $1 \times 10^{6}$ cells/flask (Becton 
Dickinson, New Jersey). The calvaria-derived bone cells were then expanded for seven days in alpha-minimal essential medium ( $\alpha$-MEM) containing 10\% fetal bovine serum and $1 \%$ penicillin/streptomycin (GIBCO BRL, Burlington, Canada) before use.

Differentiation assay. The calvaria-derived bone cells (5 $\times 10^{4}$ cells $/ 35 \mathrm{~mm}$ plate) were resuspended in $72 \pm 35 \mathrm{~mm}$ tissue-culture plates and cultured in the presence of $\alpha$-MEM supplemented with $1 \%$ non-essential amino acids, $10 \mathrm{mM} \beta$-glycerophosphate (Sigma Chemical Co, St Louis, Missouri) and $0.05 \mathrm{mM}$ ascorbic acid (Sigma Chemical Co). It is well established that calvarial cells contain osteoprogenitor cells which under the appropriate conditions (glycerophosphate and ascorbic acid) can differentiate into osteoblasts capable of forming mineralised tissue resembling woven bone. ${ }^{17}$ Media were changed every three to four days until the termination of the experiments. After 14 days, the cells were fixed and osteoblasts and adipocytes were quantified as described below.

Pressure irrigation procedure. After three days in differentiation media, 72 confluent plates were subjected to either high-pressure lavage alone $(n=24)$, low-pressure lavage alone $(n=24)$, or served as a control group $(n=24)$. A $30 \mathrm{ml}$ syringe with an 18 gauge, $3.0 \mathrm{~cm}$ catheter (Johnson \& Johnson Medical Inc, Arlington, Texas) was used to deliver the high-pressure lavage. The irrigating tip was held approximately $5 \mathrm{~cm}$ from the bone surface. This technique is well reported, and is known to deliver pressure of approximately 8 pounds per square inch (psi). ${ }^{18,19}$ Although this technique has been reported to be consistent, a single investigator (MB) performed all irrigations to minimise the inherent variability with which the syringe was depressed. Each specimen was irrigated with a total of $50 \mathrm{ml}$ of normal saline. The choice of $8 \mathrm{psi}$ for highpressure irrigation was based upon the following four factors: 1) there is no agreement in the literature regarding the absolute definition of high-pressure irrigation; ${ }^{1,2,18,19} 2$ ) 8 psi have been reported as high-pressure irrigation in recent reports; ${ }^{18,19}$ 3) 5 to 8 psi did not result in complete removal of the confluent cell layer from the culture plates; and 4) in a pilot study of irrigation pressures and viability of calvarial cells, 5 to 8 psi gave good viability of cells as determined by staining with Trypan Blue immediately after lavage (Table I). Low-pressure lavage was achieved by irrigation of the confluent cells with $50 \mathrm{ml}$ of normal saline using a bulb syringe. This technique has been previously reported to produce pressures in the range of 1 to $2 \mathrm{psi}^{20}$ Alkaline phosphatase staining. After 14 days in the differentiation assay, six plates from each of the high-pressure lavage, low-pressure lavage and control groups were used to identify the number of osteoblasts histochemically by alkalinephosphatase (ALP) staining (Sigma Chemical Co.). We used this osteoblast-specific marker because previous studies have shown that its expression correlates with the formation of bone nodules in vitro, both in the absence and presence of heparin. ${ }^{16}$ Moreover, differentiation of osteoblasts is commonly monitored by ALP, a biological marker which is expressed early in the process. Briefly, cells were fixed with $60 \%$ citrate-buffered acetone for 45 seconds. The diazonium salt solution was prepared by dissolving $12 \mathrm{mg}$ of Fast Blue salt in $50 \mathrm{ml}$ of $0.01 \%$ alkaline naphthol AS-MX phosphate. Cells were immersed in the alkaline-dye mixture for approximately 30 minutes and then counterstained with haematoxylin solution. Osteoblasts were identified by visible cytoplasmic staining of the precipitated azo dye at sites of ALP activity. The proportion of ALP-stained cells in a defined area $\left(0.25 \mathrm{~mm}^{2}\right)$ was quantified by light microscopy at $100 \times$ magnification in a blinded fashion.

Oil Red O staining. After 14 days in the differentiation assay, adipocyte-like cells in six plates from each of the three groups were identified using Oil Red $\mathrm{O}$ to stain cytoplasmic lipid droplets (triglycerides) in the cells. This staining technique has been well reported in previous studies. ${ }^{6,7}$ Oil Red O $(0.5 \mathrm{~g})$ was dissolved in $100 \mathrm{ml}$ of isopropanol, diluted 60:40 with distilled water, and then filtered using a Whatmann \#1 filter before use. Calvariaderived cell cultures were fixed with $10 \%$ formalin, stained with Oil Red O (Sigma Chemical Co) for one hour, rinsed repeatedly with distilled water to remove residual stain, and then counterstained with $0.1 \%$ Methyl Green. The proportion of adipocytes in a defined area $\left(0.25 \mathrm{~mm}^{2}\right)$ was quantified by light microscopy at $100 \times$ magnification in a blinded manner as previously reported. ${ }^{21}$

Reverse transcription-polymerase chain reaction (RTPCR). To verify whether pressure irrigation influenced the differentiation of adipocytes at a transcriptional level, mRNA levels for peroxisome proliferator activated receptor, (PPAR) $\gamma 2$, an early marker for such formation, ${ }^{22}$ were examined. In addition, to determine whether pressure irrigation influenced the differentiation of osteoblasts at a

Table I. Viable cells and lavage pressures

\begin{tabular}{lllll}
\hline \multirow{2}{*}{$\begin{array}{l}\text { Pressure } \\
\text { (psi) }\end{array}$} & Device & Cell layer & \multicolumn{2}{l}{ Viable cells* } \\
\cline { 3 - 5 } & Number & \% Total cells \\
\hline 0 (control) & - & Intact & $5.0 \times 10^{5}$ & 97 \\
1 to 2 & Bulb syringe & Intact & $4.0 \times 10^{5}$ & 95 \\
5 to 8 & $30 \mathrm{ml}$ syringe/18 gauge catheter & Intact & $3.4 \times 10^{5}$ & 81 \\
14 & Stryker $\dagger$ - low pressure setting & Partially removed & $6.0 \times 10^{4}$ & 75 \\
70 & Stryker - high pressure setting & Completely removed & 0.0 & 0 \\
\hline
\end{tabular}

* quantitated as the number of viable cells from Trypan Blue staining

$\dagger$ Stryker system (Surgilav Plus Debridement System; Stryker Instruments, Kalamazoo, Michigan) 
Table II. Primer sequences for RT-PCR

\begin{tabular}{|c|c|c|c|c|}
\hline Marker & $\begin{array}{l}\text { Accession } \\
\text { number }\end{array}$ & Sequence of primers & Product size & Cycle number \\
\hline Osteocalcin & L24431 & $\begin{array}{l}\text { Forward } \\
\text { 5'CACAATCTGCTTTGGGATGG 3' } \\
\text { Reverse } \\
\text { 5'TGCACGTCTAGCCCTCTGCAGG 3' }\end{array}$ & $414 \mathrm{bp}$ & 28 \\
\hline $\operatorname{PPAR} \gamma 2$ & U09138 & $\begin{array}{l}\text { Forward } \\
\text { 5'GTTGACACAGAGATGCCATTCTGG 3' } \\
\text { Reverse } \\
\text { 5'CACAAGCATGAACTCCATAGTGG 3' }\end{array}$ & $375 \mathrm{bp}$ & 28 \\
\hline GAPDH & M32599 & $\begin{array}{l}\text { Forward } \\
\text { 5'TGAAGGTCGGTGTGAACGGATTTGG 3' } \\
\text { Reverse } \\
\text { 5'ACGGCCATCACGCCACAGCTTTCCAGAGG 3' }\end{array}$ & $589 \mathrm{bp}$ & 20 \\
\hline
\end{tabular}

transcriptional level, mRNA levels for osteocalcin, a marker of osteoblast formation, were determined. ${ }^{6,23}$

First-strand cDNA synthesis of total mRNA by reverse transcription (RT). Total RNA was isolated from calvarial cells exposed to high-pressure irrigation $(n=12)$, lowpressure lavage $(\mathrm{n}=12)$, and the control group $(\mathrm{n}=12)$ using the RNAeasy kit (Qiagen, Toronto, Canada). The RNA was stored at $-70^{\circ} \mathrm{C}$ in $\mathrm{H}_{2} \mathrm{O}$. A total of $4 \mu \mathrm{g}$ of RNA was aliquoted in a volume of $48 \mu$ l with $2 \mu$ l of oligo d(T) primer and $\mathrm{H}_{2} \mathrm{O}$. This mixture was denatured at $70^{\circ} \mathrm{C}$ for ten minutes and quick-chilled on ice for ten minutes. A cDNA copy of all mRNA was synthesised using the superscript II (Gibco BRL) method of reverse transcription. To the reaction, $16 \mu \mathrm{l}$ of $5 \mathrm{X}$ first-strand buffer, $8 \mu \mathrm{l}$ of 0.1 MDTT and $4 \mu \mathrm{l}$ of $10 \mathrm{mM}$ each of dATP, dCTP, dGTP, dTTP and $2 \mu$ l of superscript were added and incubated at $42^{\circ} \mathrm{C}$ for one hour. Inactivation was done at $70^{\circ} \mathrm{C}$ for ten minutes and stored at $-20^{\circ} \mathrm{C}$ until use.

Primers. The specific primers used (Mobix; McMaster University, Hamilton, Canada) for the RT-PCR were $20 \mu \mathrm{M}$ solutions (Table II). The GAPDH upstream (5') primer for mouse was 5'-TGAAGGTCGGTGTGAACGGATTTGG 3' and downstream (3') 5'-ACGGCCATCACGCCACAGCTTTCCAGAGG-3'. The specific cytokine primers for osteocalcin were upstream (5') 5'-CACAATCTGCTTTGGGATGG-3' and downstream (3') 5'-TGCACGTCTAGCCCTCTGCAGG 3'. For PPAR $\gamma 2^{24}$ the upstream primer (5') was 5'-GTTGACACAGAGATGCCATTCTGG-3' and downstream (3') 5'-CACAAGCATGAACTCCATAGTG-3'.

Polymerase chain reaction (PCR). The PCR reaction was performed using $2 \mu \mathrm{l}$ of the RT reaction with $18 \mu \mathrm{l}$ of PCR Supermix (Gibco BRL). To each reaction, $0.5 \mu \mathrm{l}$ of a $20 \mu \mathrm{M}$ Forward primer mix and $1 \mu \mathrm{l}$ of $\gamma^{32} \mathrm{P}$ labelled reverse mixture were added (either osteocalcin or PPAR $\gamma$ ) (Table II). Each microlitre of the reverse primer contained $0.5 \mu \mathrm{l}$ of $20 \mu \mathrm{M}$ stock primer, $0.14 \mu \mathrm{l} \mathrm{H}_{2} 0,0.06 \mu \mathrm{l}$ of T4kinase (Gibco BRL, Mississauga, Canada), $0.01 \mu l$ of $\gamma^{32} \mathrm{P}$ (Mandel, Toronto, Canada) and $0.2 \mu \mathrm{l}$ of $5 \mathrm{X}$ Forward reaction buffer. This mixture was incubated at $37^{\circ} \mathrm{C}$ for one hour and was followed by inactivation at $70^{\circ} \mathrm{C}$ for ten minutes. The products were stored at $-20^{\circ} \mathrm{C}$.
The PCR reactions were set up on ice, overlayed with mineral oil and performed in triplicate using a programmable thermal controller (MJ Research Inc, Chicago, Illinois). Conditions for cycling were as follows: 1) an initial denaturation step of $94^{\circ} \mathrm{C}$ for two minutes; and 2) the appropriate number of cycles of $94^{\circ} \mathrm{C}$ for one minute, $65^{\circ} \mathrm{C}$ for one minute and $72^{\circ} \mathrm{C}$ for one minute. The number of cycles was determined by initially performing cycle number analysis at a point on the low end of the saturation curve. This was found to be 20,28 and 28 cycles, respectively, for GAPDH, osteocalcin and PPAR $\gamma 2$. The amplification products were analysed on $5 \%$ polyacrylamide gel electrophoresis and visualised by drying the gels, and exposing to film. Quantitative analysis was performed using volume quantification on a phosphoimaging system (Molecular Dynamics, Ottawa, Canada). ${ }^{5}$

Statistical analysis. The number of ALP and Oil Red Ostaining cells were compared for the treatment groups with single-factor analysis of variance (ANOVA). Specific pairwise comparisons between treatment groups were further evaluated by independent $t$-tests. Equality of variances between treatment groups was examined and if inequality was found, $t$-tests for unequal variances were performed. The least significance difference (LSD) tests were applied to adjust for multiple comparisons. All tests were two-tailed and $\mathrm{p}<0.05$ was considered to give statistical significance. All means are presented with the standard error (SEM).

\section{Results}

The effect of pulsatile lavage on Oil Red $O$ stained cells. Significant differences were found between highpressure lavage, low-pressure lavage and the control group in Oil-Red-O-stained cells (ANOVA, $\mathrm{p}<0.05$ ). When specific comparisons between groups were performed, high-pressure lavage (8 psi) resulted in a significant increase in the number of the Oil-Red-O-stained cells when compared with low-pressure lavage (1 to 2 psi) $(800 \pm 70.7 v 535 \pm 56.1$, respectively; $\mathrm{p}=0.02$ corrected for multiple comparisons) (Fig. 1). Thus, highpressure lavage resulted in an increase of $49.5 \%$ of adipocyte-like cell genesis compared with low-pressure 


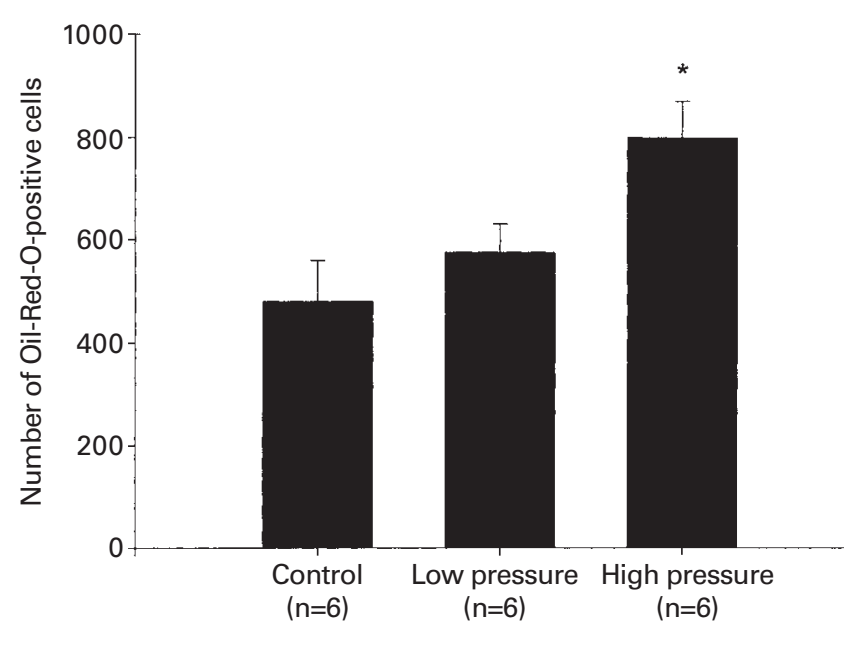

Fig. 1

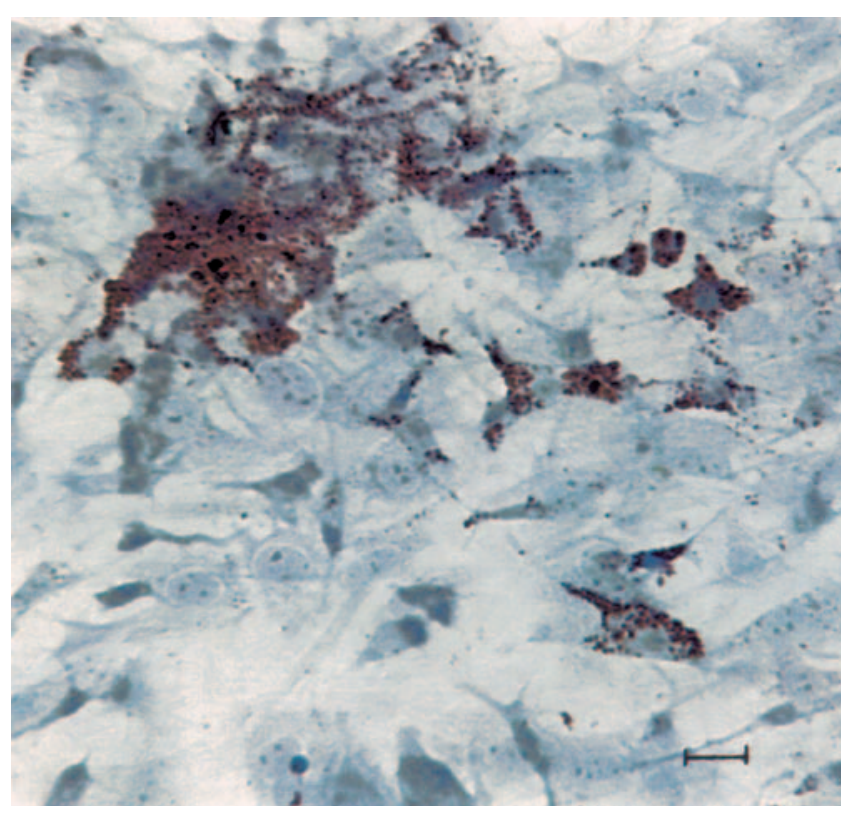

Fig. 2

Photomicrograph showing adipocyte-like cells with lipid vesicles in the cytoplasm after high-pressure lavage (bar length $=30 \mu \mathrm{m}$; Oil Red O)
Bar chart showing the effect of irrigation pressure on the number of OilRed-O-stained cells in vitro, in the control, high-pressure lavage and lowpressure lavage groups. $(\mathrm{p}<0.05$ when compared with the control group).

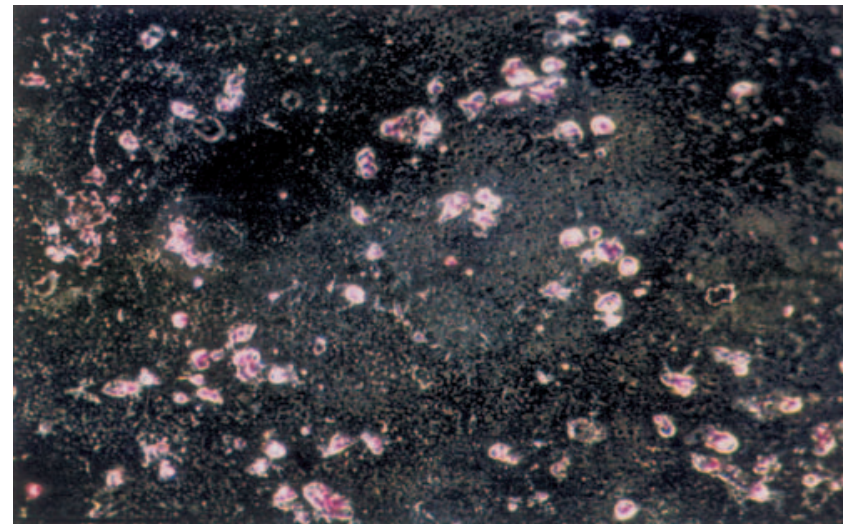

Fig. 3a

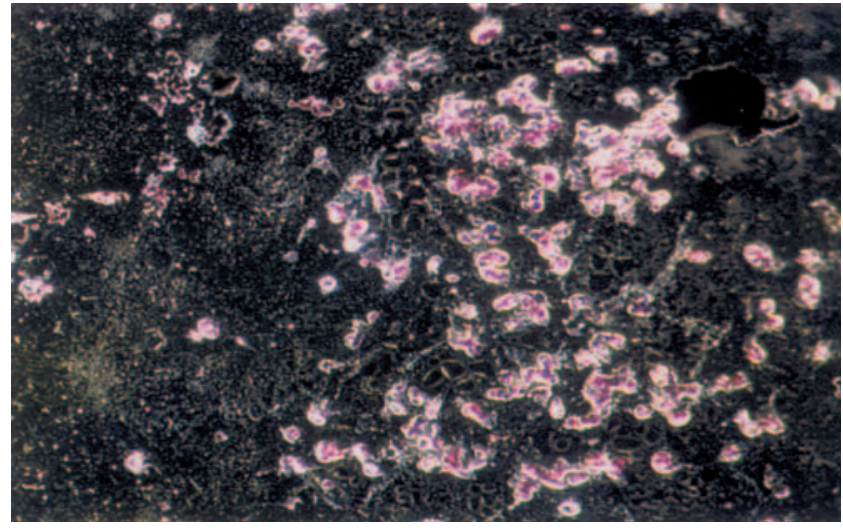

Fig. 3b

Photomicrographs showing adipocyte-like cell formation after a) low-pressure and $b)$ high-pressure lavage $(\times 35)$.

irrigation, and an increase of $75 \%$ compared with the control group (Figs 2 and 3). Moreover, the number of adipocyte-like cells in the low-pressure irrigation and control groups did not differ significantly $(535 \pm 56.1 \mathrm{v}$ $490 \pm 51.6, \mathrm{p}=0.54)$.

The level of PPAR $\gamma 2$ mRNA in calvarial cells exposed to high-pressure lavage was 1.3 times greater than in cells exposed to low-pressure lavage and 1.6 times greater than in control cells (Fig. 4).

Effect of pulsatile lavage on ALP stained cells. Significant differences in ALP staining between cells exposed to high-pressure lavage and low-pressure lavage and the control group were observed (ANOVA, $\mathrm{p}<0.05$ ). When specific comparisons between groups were performed, high-pressure lavage ( $8 \mathrm{psi}$ ) gave a significant decrease in the number of ALP-stained cells when compared with lowpressure lavage ( 1 to 2 psi) $(179.5 \pm 19.4 \vee 640 \pm 119.2$, respectively; $p=0.02$ ) (Fig. 5). Compared with the control group, high-pressure lavage decreased the number of ALPstained cells by $90 \%$ whereas low pressure decreased them by $65 \%(1800 \pm 189.5,179.5 \pm 19.4$ and $640 \pm 119.2$, respectively). Furthermore, high-pressure lavage gave a ten times greater decline in the number of ALP-stained cells compared with control cells $(179.5 \pm 19.4 v 1800 \pm 189.5)$ (Figs 5 and 6).

Lavage of the calvarial cells led to a decline in the expression of osteocalcin in both high- and low-pressureexposed cells (Fig. 4). 


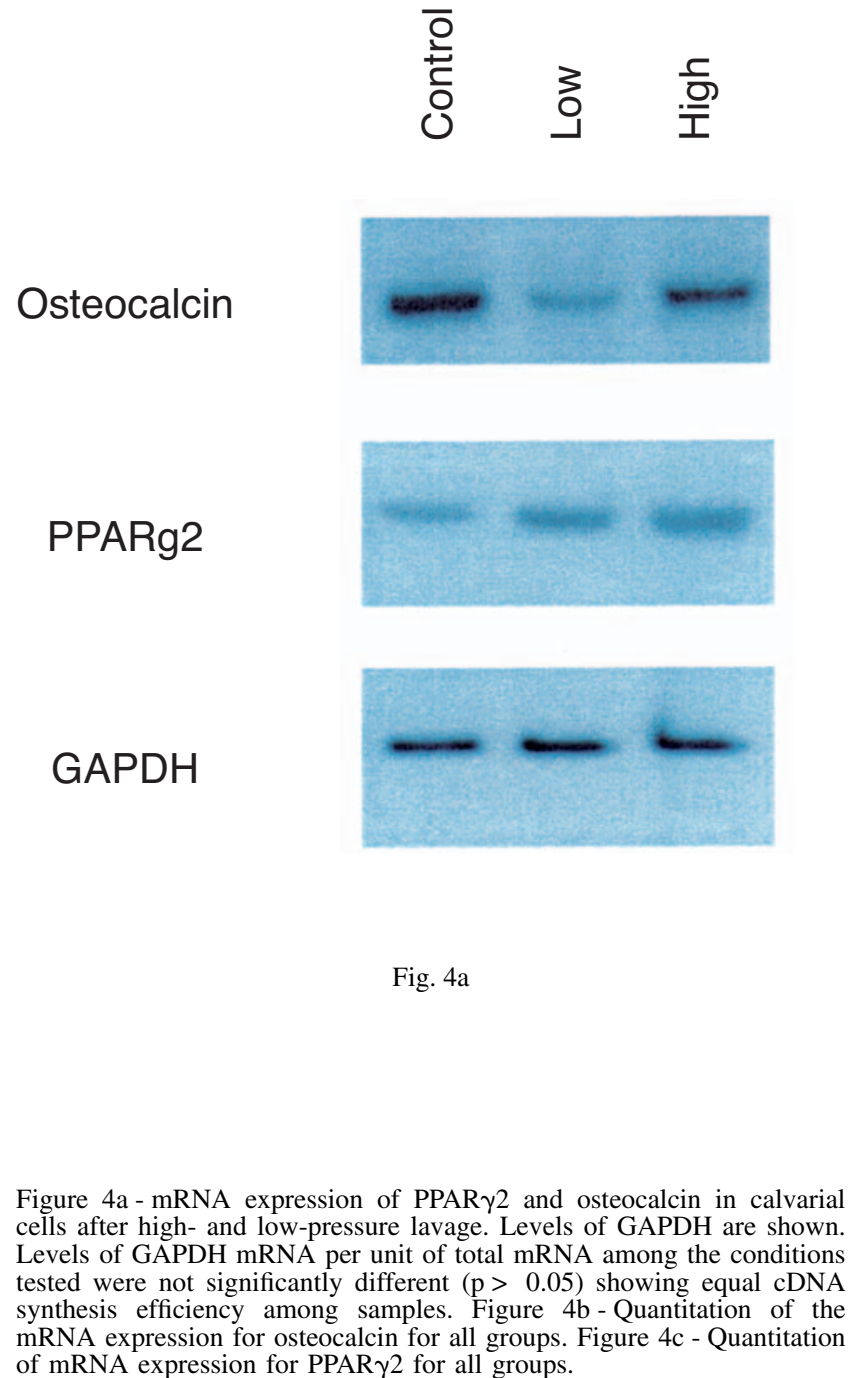

of mRNA expression for PPAR 2 for all groups.

Correlation between osteoblast and adipocyte cell numbers. The decline in osteoblast numbers was highly correlated with an increase in adipocyte-like cells as the irrigation pressure increased from the control to high pressure $(r=0.82$; Fig. 7$)$.

\section{Discussion}

It is now generally accepted that osteoblasts arise by differentiation from multipotential progenitor cells within the bone-marrow stroma which are also capable of committing to other mesenchymal lineages, including fibroblasts, myoblasts, chondrocytes, adipocytes and osteoblasts. ${ }^{5-13}$ Considerable work has focused on the specific relationship between osteoblasts and adipocytes. Specifically, those conditions associated with bone loss, such as ovariectomy, glucocorticoid treatment, or immobilisation, are associated with an increase in marrow adipocytes. ${ }^{25-27}$ One possible mechanism for the decline in bone volume, and thus mechanical strength, is an imbalance in the differentiation of progenitors of the osteoblast and adipocyte lineages at

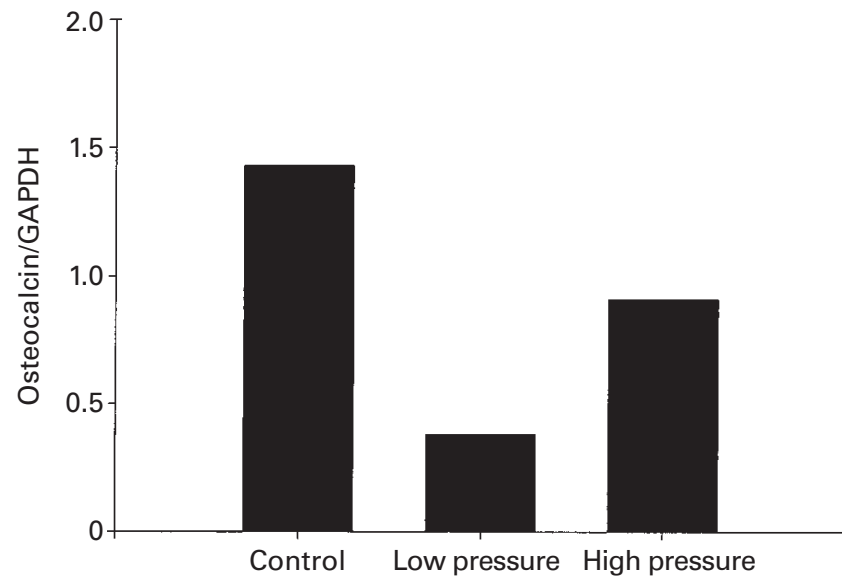

Fig. 4b

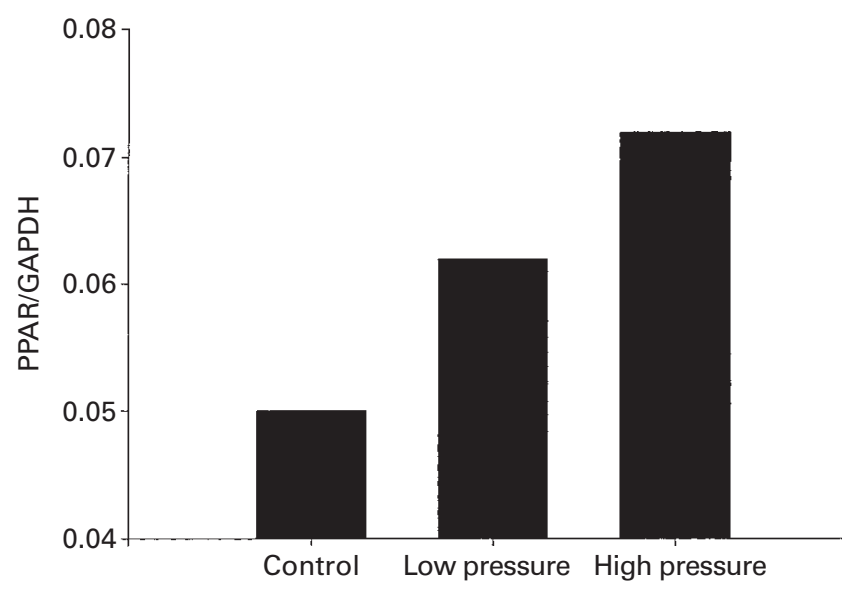

Fig. $4 \mathrm{c}$

the expense of the osteoblast. This theory has been confirmed in histomorphometric studies which have shown adipose replacement of the marrow in osteoporosis. ${ }^{23}$

The precise role of adipocytes in the bone marrow is unknown. It has been suggested that they act simply in a passive role filling marrow cavities not required for active haematopoiesis. However, adipocytes may also be involved in the energy metabolism of the active osteoclast, or they may participate in overall metabolism by clearing and storing circulating triglycerides. ${ }^{28}$

High-pressure lavage has been used extensively in the debridement of contaminated fractures with soft-tissue wounds. ${ }^{1-3}$ However, its deleterious effects on bone have only recently been reported. ${ }^{1-3}$ In addition to visible macroscopic bone damage, high-pressure lavage has been shown to produce microscopic fissuring and periosteal stripping of cortical bone. ${ }^{2}$ Dirschl et $\mathrm{al}^{3}$ examined the effect of highpressure lavage in New Zealand White rabbits undergoing healing of fractures. They reported reduction of $21 \%$ in early formation of new bone (within two weeks of fracture) with high-pressure lavage. Moreover, $30 \%$ of the fractures 


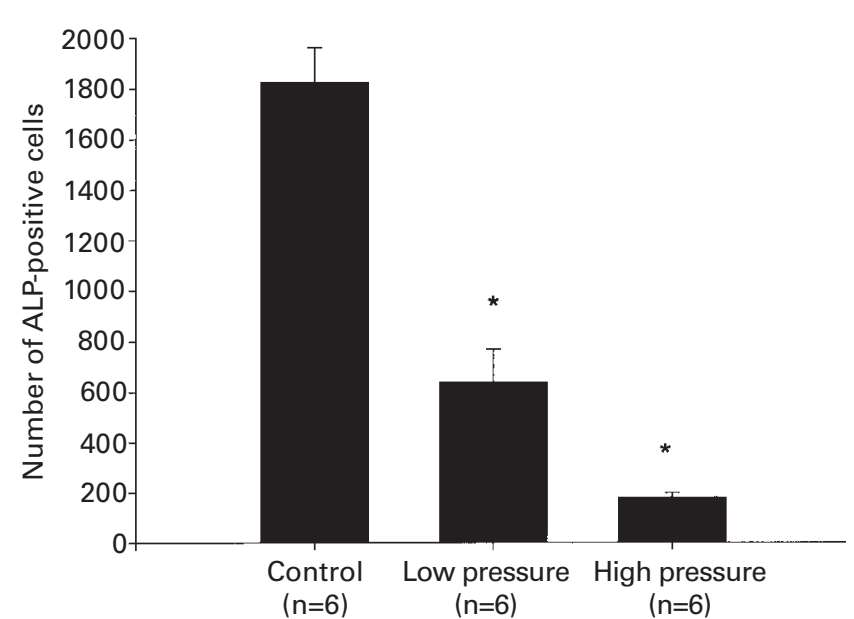

Fig. 5

Bar chart showing the effect of irrigation pressure on the number of ALPstained cells in vitro $(\mathrm{p}<0.05$ when compared with the controls).

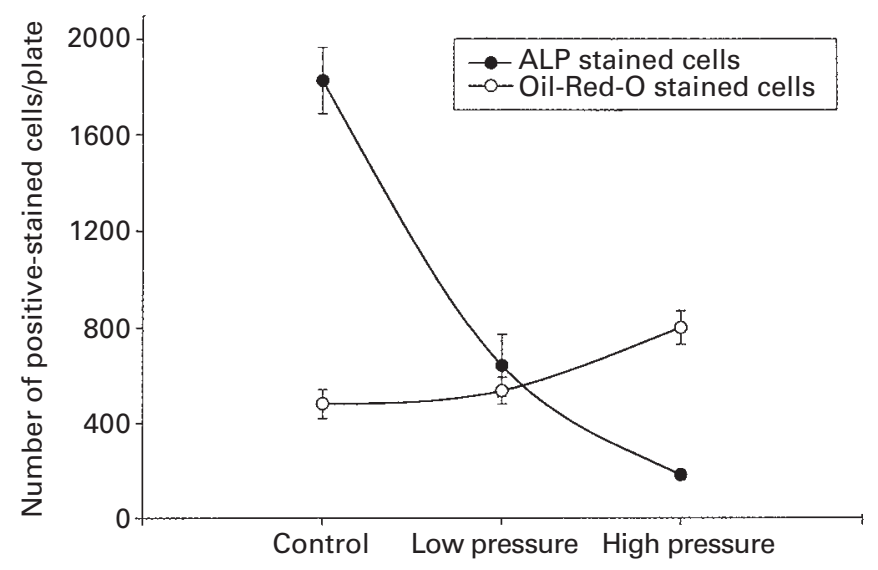

Fig. 7

Graph showing decline in osteoblast numbers $v$ the increase in adipocyte numbers with increasing irrigation pressure.

exposed to high-pressure lavage failed to unite compared with $20 \%$ in the control group. ${ }^{3}$

The definition of high-pressure lavage has varied in the literature. ${ }^{1,2,18,19}$ Since there is no agreement on a 'cut-off' point for high-pressure lavage, it may be more useful to view pressure irrigation on a continuum. Therefore, while 8 psi have been defined as low pressure in studies examining its macroscopic effects ${ }^{2,3}$ we have considered it to be 'relatively' higher pressure at the microscopic level. To our knowledge, we are the first to show that lavage, at a clinically relevant pressure (8 psi), produces an increase in adipocytes at the expense of osteoblasts. This effect is less pronounced with low-pressure lavage (1 to $2 \mathrm{psi}$ ). These conclusions are strengthened by the in vitro cell culture model used and our confidence in identifying both osteoblasts and adipocytes.

Osteoblastic cells released from fetal calvaria are a widely used model. In the presence of serum, these cells will differentiate over time and pass through the successive

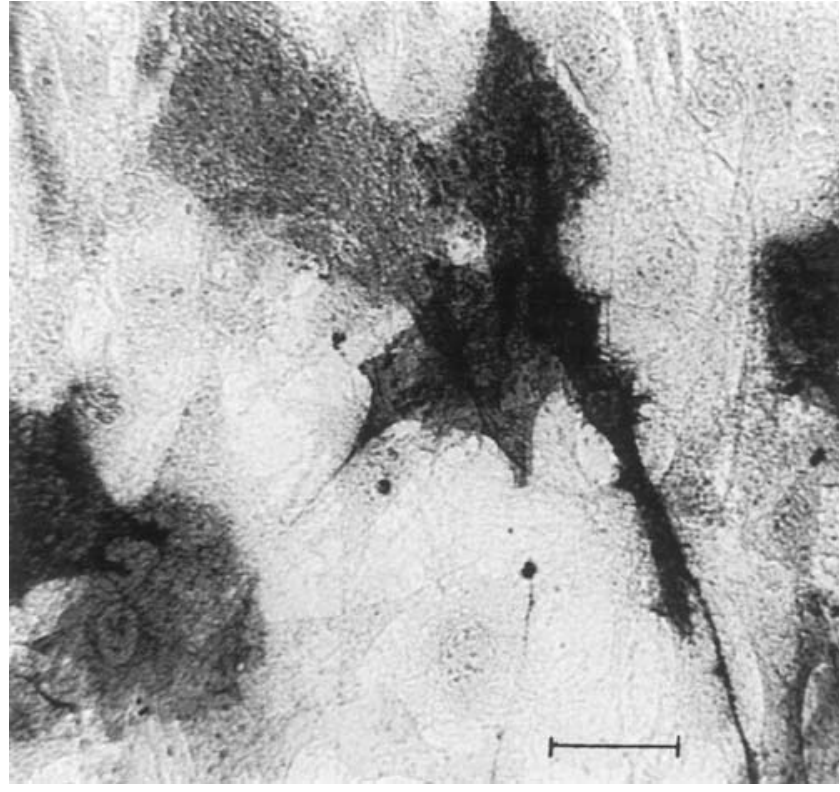

Fig. 6

Photomicrograph of ALP-stained cells (dark) after high-pressure lavage $($ bar $=10 \mu \mathrm{m})$

stages of proliferation and formation, maturation, and mineralisation of the matrix with each stage characterised by a specific pattern of gene expression. ${ }^{5,19}$

The differentiation of osteoblasts was monitored by two markers, ALP and osteocalcin, sequentially expressed during the differentiation process. ${ }^{6}$ ALP is one of the earliest markers expressed by an immature osteoblast, and its expression persists throughout the maturation of the osteoblast. We found significant reductions $(90 \%)$ in ALPstained cells with high-pressure lavage compared with the control group. Hillsley and Frangos ${ }^{29}$ subjected calvarial cells to fluid flow (5 dynes/cm) and found a reduction of $70 \%$ in levels of ALP after three hours of exposure. Despite the significantly greater fluid pressures used in our current study, we found a similar decline in osteoblasts. Further confirmation of the findings from ALP staining were obtained from osteocalcin mRNA expression. Stanford et $\mathrm{al}^{24}$ evaluated the effect of cellular deformation on osteocalcin expression in calvarial cells. They reported that even small magnitudes of cellular deformation reproducibly depressed the osteocalcin message.

The differentiation of adipocytes was monitored by the well-reported technique of Oil-Red-O-staining of the lipid droplets, which accumulate in their cytoplasm. ${ }^{5-7}$ We confirmed the presence of adipocytes by the expression of a specific receptor, PPAR $\gamma 2$, found in adipocytes. Recently, the PPARs, a group of receptors which belong to the steroid hormone receptor superfamily, have been implicated in the control of differentiation of adipocytes. ${ }^{30}$ The PPAR family is composed of three receptors, PPAR $\alpha$, PPAR $\delta$, and $\operatorname{PPAR} \gamma .{ }^{9}$ The last is primarily expressed in adipose tissue 
and the immune system. ${ }^{30}$ Moreover, the peroxisome proliferator response element has been identified in the promoter regions of several enzymes associated with the metabolism of triglycerides. ${ }^{30}$

The mechanism by which high-pressure lavage influences the differentiation of mesenchymal stem cells is uncertain. The decline in osteoblasts after high-pressure lavage may have occurred as a consequence of immediate cell lysis from trauma, delayed cell apoptosis, or an alteration of the differentiation pathway of the stem cells. We found that, at the pressures utilised for the study, most cells were viable immediately after lavage. This provides persuasive evidence against direct cell lysis from trauma.

A variety of factors, including interleukin $1-\beta$, tumour necrosis factor- $\alpha$ and bone morphogenetic proteins (BMP) have been implicated in altering the differentiation pathway of mesenchymal stem cells towards osteoblasts or adipocytes. $^{31}$ Moreover, osteoblasts contain receptors for IL-6, IL-11, LIF, oncostatin $\mathrm{M}$, and ciliary neurotrophic factor. ${ }^{32}$ These cytokines share a common gp 130 signal transduction protein and are known to modulate bone metabolism. ${ }^{32}$ Thus, it is possible that high-pressure lavage alters the expression of one or more of these cytokines.

Open fractures with soft-tissue contamination typically undergo thorough and meticulous debridement and highpressure irrigation with several litres of saline. ${ }^{33,34}$ During the initial stages of the healing of fractures, it may be hypothesised that high-pressure lavage may result in a switch in the differentiation of mesenchymal stem cells towards the adipocyte lineage. Bennett et $\mathrm{al}^{13}$ have shown that both preadipocytes and mature adipocytes may rapidly become fibroblastic. ${ }^{13}$ They have further defined the series of cell changes which accompany the conversion from adipocytes to fibroblasts. These include a change from rounded or polygonal cells with cytoplasmic lipid droplets (adipocytes) to spindle-shaped cells without lipid droplets (fibroblast precursors). ${ }^{13}$ Thus, a decline in osteoblasts and an increase in adipocyte-like cells may be early cellular changes which could lead to a delay in the process of healing and potentially result in fibrous nonunion.

Our findings suggest that, in addition to mechanical damage, high-pressure lavage may promote differentiation of mesenchymal stem cells towards the adipocyte lineage. These findings may have clinical significance in the development of delayed and nonunion in those open fractures initially debrided with high-pressure irrigation.

We gratefully acknowledge the assistance of Joanne Duncan in developing the protocol for RT-PCR. This study was funded by a research grant from the Canadian Orthopaedic Foundation.

No benefits in any form have been received or will be received from a commercial party related directly or indirectly to the subject of this article.

\section{References}

1. Bhandari M, Adili A, Lachowski RJ. High pressure pulsatile lavage of contaminated human tibiae: an in-vitro study. J Orthop Trauma 1998;12:479-84.
2. Bhandari M, Schemitsch EH, Adili A, Lachowski RJ, Shaughnessy SG. High and low pressure pulsatile lavage of contaminated tibial fractures: an in vitro study of bacterial adherence and bone damage. J Orthop Trauma 1999;13:526-33.

3. Dirschl DR, Duff GP, Dahners LE, et al. High pressure pulsatile irrigation of intraarticular fractures: effects on fracture healing. $J$ Orthop Trauma 1998;12:460-3.

4. Kajkenova O, Lecka-Czernik B, Gubrij I, et al. Increased adipogenesis and myelopoiesis in the bone marrow of SAMP6, a murine model of defective osteoblastogenesis and low turnover osteopenia. J Bone Miner Res 1997;12:1772-9.

5. Hicok K, Thomas T, Gori F, et al. Development and characterization of conditionally immortalized osteoblast precursor cell lines from human marrow stroma. J Bone Miner Res 1998;13:205-17.

6. Thompson D, Lum K, Nygaard $S$, et al. The derivation and characterization of stromal cell lines from the bone marrow of p53/-mice: new insights into osteoblast and adipocyte differentiation. $J$ Bone Miner Res 1998;13:195-204.

7. Nuttal ME, Patton A, Olivera D, Nadeau DP, Gowen M. Human trabecular bone cells are able to express both osteoblastic and adipocytic phenotype: implications for osteopenic disorders. $J$ Bone Miner Res 1998;13:371-82.

8. Grigoriadis AE, Heersche JM, Aubin JE. Continuously growing biopotential and monopotential myogenic, adipogenic, and chondrogenic subclones isolated from the multipotential RCJ 3.1 clonal cell line. Dev Biol 1990;142:313-8.

9. Diascro DD, Vogel RL, Johnson TE, et al. High fatty acid content in rabbit serum is responsible for the differentiation of osteoblasts into adipocyte-like cells. J Bone Miner Res 1998;13:96-106.

10. Poliard A, Nifuji A, Lamblin D, et al. Controlled conversion of an immortalized mesodermal progenitor cell towards osteogenic, chondrogenic, or adipogenic pathways. $J$ Cell Biol 1995;130:1461-72.

11. Grigoriadis AE, Heersche JM, Aubin JE. Differentiation of muscle, fat, cartilage, and bone progenitor cells present in a bonederived clonal cell population: effect of dexamethasone. J Cell Biol 1988;106:2139-51.

12. Beresford J, Bennett JH, Devlin C, Leboy PS, Owen ME. Evidence for an inverse relationship between the differentiation of adipocytic and osteogenic cells in rat marrow stromal cell structures. $J$ Cell Sci 1992;102:341-51.

13. Bennett JH, Joyner C, Triffitt J, Owen ME. Adipocytic cells cultured from marrow have osteogenic potential. J Cell Sci 1991;99:131-9.

14. Gimble JM, Robinson CE, Wu X, Kelly KA. The function of adipocytes in the bone marrow stroma: an update. Bone 1996;19:421-8.

15. Moore SG, Dawson KL. Red and yellow marrow in the femur: agerelated changes in appearance at MR imaging. Radiology 1990;175:219-23.

16. Bhandari M, Hirsh J, Weitz JI, et al. The effects of standard and low molecular weight heparin on bone nodule formation in vitro. Thromb Haemost 1998;80:413-7.

17. Bellows CG, Aubin JE, Heersche JNM, Antosz ME. Mineralized bone nodules formed in vitro from enzymatically released rat calvaria cell populations. Calcif Tissue Int 1986;38:143-54.

18. Pronchik D, Barber C, Rittenhouse S. Low-versus high-pressure irrigation techniques in Staphylococcus aureus-inoculated wounds. Am J Emerg Med 1999;17:121-4.

19. Morse JW, Babson T, Camasso C, Bush AC, Blythe PA. Wound infection rate and irrigation pressure of two potential new wound irrigation devices: the port and the cap. Am J Emerg Med 1998; 16:37-42.

20. Singer AJ, Hollander JE, Subramanian S, Malhotra AK, Villez PA. Pressure dynamics of various irrigation techniques commonly used in the emergency department. Ann Emerg Med 1994;24:36-40.

21. Bhandari M, Walton K, Hirsh J, Weitz J, Shaughnessy S. Differential effects of heparin and low molecular weight heparin on osteoblastogenesis and adipogenesis in vitro. Blood 1998;92:1474.

22. Tontonoz P, Hu E, Graves RA, Budavari AL, Spiegelman BM. mPPAR gamma 2: a tissue specific regulator of an adipocyte enhancer. Genes Dev 1994;8:1224-34.

23. Beresford JN. Osteogenic stem cells and the stromal system of bone and marrow. Clin Orthop 1989;240:270-80. 
24. Stanford CM, Stevens JW, Brand RA. Cellular deformation reversibly depresses RT-PCR detectable levels of bone-related mRNA. $J$

25. Wronski TJ, Walsh CC, Ignaszewski LA. Histologic evidence for osteopenia and increased bone turnover in ovariectomized rats. Bone 1986;7:119-23.

26. Minaire P, Meunier PJ, Edouard C, et al. Quantitative histological data on disuse osteoporosis. Calcif Tissue Int 1974;17:57-73.

27. Wang GW, Sweet D, Reger S, Thompson R. Fat cell changes as a mechanism of avascular necrosis in the femoral head in cortisonetreated rabbits. J Bone Joint Surg [Am] 1977;59-A:729-35.

28. Hussain MM, Mahley RW, Boyles JK, et al. Chylomicron metabolism: chylomicron uptake by bone marrow in different animal species. J Biol Chem 1989;264:17931-8.

29. Hillsley MV, Frangos JA. Alkaline phosphatase in osteoblasts is downregulated by pulsatile fluid flow. Calcif Tissue Int 1997;60:48-53.
30. Tontonoz P, Hu E, Graves RA, Budavari AI, Speigelman BM. mPPAR gamma 2: tissue-specific regulator of an adipocyte enhancer. Genes Dev 1994;8:1224-34.

31. Gimble JM, Morgan C, Kelly K, et al. Bone morphogenetic proteins inhibit adipocyte differentiation by bone marrow stromal cells. $J$ Cell Biochem 1995;58:393-402.

32. Bellido T, Stahl N, Farruggella TJ, et al. Detection of receptors for interleukin-6, interleukin-11, leukemia inhibitory factor, oncostatin $\mathrm{M}$, and ciliary neurotrophic factor in bone marrow stromal/osteoblastic cells. J Clin Invest 1996;97:431-7.

33. Chapman M. Open fractures. In: Rockwood CA, Green DP, Bucholz RW, eds. Fractures in adults. 3rd ed. Philadelphia, JB Lippincott, 1991, 223-64.

34. Gustilo RB, Merkow RL, Templeman D. The management of open fractures. J Bone Joint Surg [Am] 1990;72-A:299-304. 